\title{
BIOSYNTHESIS OF $\triangle$-AMINOLEVULINATE IN GREENING BARLEY LEAVES IV. ISOLATION OF THREE SOLUBLE ENZYMES REQUIRED FOR THE CONVERSION OF GLUTAMATE TO $\triangle$-AMINOLEVULINATE
}

\author{
by \\ WEI-YEH WANG, SIMON P. GOUGH and C. GAMINI KANNANGARA \\ Department of Physiology, Carisberg Laboratory \\ Gamle Carlsberg Vej 10, DK-2500 Copenhagen-Valby \\ and \\ Department of Botany, University of Iowa, Iowa City, Iowa 52242 USA
}

Keywords: Heme-Sepharose, Blue Sepharose, affinity chromatography, high pressure liquid chromatography, glutamate-l-semialdehyde aminotransferase, glutamine synthetase, glutamate-l-phosphate kinase, glutamate-l-phosphate dehydrogenase, $\delta$-aminolevulinate dehydratase, porphobilinogen deaminase, uroporphyrinogen

The soluble enzymes converting glutamate into $\delta$-aminolevulinate and subsequently into uroporphyrinogen were partially purified from the stroma of greening barley plastids using Sephacryl S-300 gel filtration. By affinity chromatography employing sequentially Blue Sepharose, Matrex Gel Red A and heme-Sepharose the partially purified enzymes were separated into three fractions which together are required to catalyze the synthesis of $\delta$-aminolevulinate from glutamate: proteins binding to Blue Sepharose, proteins binding to hemeSepharose and run-off proteins not retained by the three columns. By analysing the characteristics of these fractions the following conclusions are reached:

1. Conversion of glutamate into glutamate-1-semialdehyde in the presence of ATP, $\mathrm{Mg}^{2+}$ and NADPH requires at least two proteins, one binding to heme-Sepharose and one binding to Blue Sepharose.

2. Glutamate-1-semialdehyde is converted into $\delta$-aminolevulinate by glutamate-l-semialdehyde aminotransferase, which is not retained on the affinity columns.

3. The run-off protein fraction also contains $\delta$-aminolevulinate dehydratase and porphobilinogen deaminase

4. The heme-Sepharose bound protein(s) probably converts glutamate to glutamate-l-phosphate in the presence of ATP and $\mathrm{Mg}^{2+}$ and the Blue-Sepharose bound protein(s), glutamate-l-phosphate to glutamate-l-semialdehyde, in the presence of NADPH. 


\section{INTRODUCTION}

In the developing chloroplast $\delta$-aminolevulinate is synthesised from glutamate by soluble enzymes $(4,7,11,20)$. The rate limiting step in the chlorophyll pathway is the synthesis of $\delta$ aminolevulinate $(3,5,11,15)$. Its formation in vitro is strongly inhibited by heme (8) and has been proposed to proceed in the following way: Glutamate is converted into glutamate-1-phosphate, which is reduced to glutamate-1-semialdehyde and the aldehyde transaminated to $\delta$ aminolevulinate (14). The enzyme catalysing the last step, glumatate-l-semialdehyde aminotransferase has been isolated and purified (16).

This paper describes how we separated the $\delta$ aminolevulinate synthesising plastid stroma preparation into three components and studied the characteristics of these components.

\section{MATERIALS AND METHODS \\ 2.1. Chemicals}

$\mathrm{N}$-ethyl-N'-(3-dimethylaminopropyl)-carbodiimide hydrochloride was obtained from Fluka AG, Switzerland. Na-lauryl sulphonate (specially pure for biochemical studies) and t-amyl alcohol from British Drug Houses, UK. Hemin, NADPH, L-methionine DL-sulphoximine and ATP were obtained from Sigma, USA. Lglutamate-U- ${ }^{14} \mathrm{C}\left(275 \mathrm{mCi} \cdot \mathrm{mmole}^{-1}\right)$ was obtained from Amersham, UK. Sephacryl S-300, Blue Sepharose CL-6B and AH Sepharose-4B were obtained from Pharmacia, Sweden. Matrex Gel Red A was from Amicon, USA. Glutamatel-semialdehyde was synthesised from N-carbobenzoxy-L-glutamic acid $\gamma$-benzyl ester (Bachem, Switzerland) as described previously (14). Porphobilinogen was obtained from Porphyrin Products, USA.

\subsection{Preparation of heme-Sepharose}

Heme was linked to the amino group of the six-carbon spacer of AH-Sepharose-4B in the following manner. Hemin (134 mg, $200 \mu$ mole) was mixed with $0.5 \mathrm{ml}$ of $\mathrm{I} \mathrm{M}-\mathrm{NaOH}$ and dissolved by the addition of $100 \mathrm{ml}$ methanol. Forty $\mathrm{ml}$ of $0.01 \mathrm{M}-\mathrm{HCl}$ were added to the heme solution while stirring, thus changing the reading of a $\mathrm{pH}$ meter to $\mathrm{pH} 7.2$. Water $(60 \mathrm{ml})$ was then added. It was found essential to maintain the $\mathrm{pH}$ reading above 7.0 to prevent precipitation of heme. AH-Sepharose-4B (5 g) was swollen in $200 \mathrm{ml}$ of $0.5 \mathrm{M}-\mathrm{NaCl}$ and washed with $1000 \mathrm{ml}$ of $0.5 \mathrm{M}-\mathrm{NaCl}$ followed by $1000 \mathrm{ml}$ of distilled water. The heme solution was added to the gel suspension. N-ethyl-N'-(3dimethylaminopropyl)-carbodiimide hydrochloride (38 mg, 250 umoles, in $1 \mathrm{ml}$ water) was added dropwise to the heme gel mixture. The suspension was shaken at room temperature for at least 24 hours in darkness. In the first hour of incubation the $\mathrm{pH}$ of the solution was maintained above 7.0 using $0.1 \mathrm{M}-\mathrm{NaOH}$. At the end of the incubation the gel beads appeared dark brown. The heme-Sepharose gel was removed from the solution by centrifugation at $600 \mathrm{~g}$ for 5 min (representing standard procedure unless otherwise mentioned) and washed alternately with acidic ( $10 \%$ acetic acid) and alkaline (1\% $\mathrm{NaOH}$ ) solutions of $50 \%$ methanol containing 1 $\mathrm{M}-\mathrm{NaCl}$. The washing was continued until no more heme leached out from the gel beads.

\subsection{Plant material}

Three $\mathrm{kg}$ of barley seeds (Hordeum vulgare L.cv. Svalöfs Bonus) were germinated and grown on plastic trays containing moist vermiculite in a dark room kept at $23^{\circ} \mathrm{C}$ and 70 to $80 \%$ relative humidity. After six days of growth the seedlings were greened under „Osram Fluorak fluorescent light for six hours. Leaves were harvested, wrapped in aluminium foil and cooled in ice.

\subsection{Isolation of plastids and stroma proteins}

All steps of enzyme isolation were carried out at 0 to $4{ }^{\circ} \mathrm{C}$. The leaves were homogenised in 0.6 M-glycerol, 0.1 м-Tricine- $\mathrm{NaOH}$ (pH 9.0) using a blender fitted with replaceable razor blades (17). The homogenate was squeezed through two layers of nylon mesh $(31 \mu)$ and centrifuged at $1,400 \mathrm{~g}$ for five minutes. The plastid pellet was suspended in a solution of $0.3 \mathrm{M}$-glycerol, $0.1 \mathrm{M}$ Tricine- $\mathrm{NaOH}$ ( $\mathrm{pH} \mathrm{9.0),} 1$ mM-dithiothreitol and $1 \mathrm{~mm}-\mathrm{MgCl}_{2}$ then disrupted by passing through an Amicon French pressure cell at 8000 psi. The disrupted plastids were centrifuged at $226,000 \mathrm{~g}$ for 20 minutes and the supernatant containing the stroma proteins collected. 


\subsection{Purification of glutamate-l-semialdehyde aminotransferase}

The glutamate-1-semialdehyde aminotransferase was purified (16) by sequential chromatography on DEAE-Sephadex A25, Sepharose 6B, Biogel A 0.5 and Sephacryl S-200. The equilibration and basic elution medium used was 0.3 M-glycerol, 0.1 M-Tricine- $\mathrm{NaOH}$ (pH 7.9), 1 mmdithiothreitol and $1 \mathrm{~mm}-\mathrm{MgCl}_{2}$. Stroma proteins ( $3.84 \mathrm{~g}$ protein) were applied batchwise to the DEAE-Sephadex A 25 column $(38 \times 2.5 \mathrm{~cm})$ and washed with $320 \mathrm{ml}$ of elution medium and eluted then with a linear gradient of $\mathrm{NaCl}(0$ to $0.5 \mathrm{M})$ in the same medium. Glutamate-1semialdehyde aminotransferase eluted at about $0.23 \mathrm{M}-\mathrm{NaCl}$. The active fractions were pooled and concentrated by pressure dialysis to about 10 $\mathrm{ml}$ using an Amicon PM30 filter. The concentrate was applied to a Sepharose 6B column $(5 \times 48 \mathrm{~cm})$. Eight $\mathrm{ml}$ fractions were collected. The active fractions eluted around fraction 90 and were pooled and concentrated to $10 \mathrm{ml}$. The proteins were then applied to a Biogel A 0.5 column $(5 \times 50 \mathrm{~cm})$ and eluted as a broad peak around fraction $60(8 \mathrm{ml}$ fractions). After the fractions containing aminotransferase were pooled and concentrated to $10 \mathrm{ml}$ they were fractionated on a Sephacryl S-200 column $(80 \times 2.5 \mathrm{~cm})$. The fraction size were eight $\mathrm{ml}$. The activity eluted around fraction 33 and was concentrated to give purified aminotransferase (specific activity, 70 nmole $\delta$-aminolevulinate $\cdot \mathrm{mg}$ protein $^{-1} \cdot$ minute $\left.^{-1}\right)$. Gel electrophoresis on a $7.0 \%$ polyacrylamide column $(5 \times 110$ $\mathrm{mm}$ ) of the purified aminotransferase revealed five bands staining with Comassie blue. Enzyme assays with unstained gels showed that one of the bands was aminotransferase.

\subsection{Column elution medium and the desalting and concentration of proteins}

The elution medium consisted of $0.3 \mathrm{M}$ glycerol, 0.1 м-Tricine- $\mathrm{NaOH}(\mathrm{pH}$ 9), 1 mмdithiothreitol and $25 \mathrm{~mm}-\mathrm{MgCl}_{2}$ and was used as the standard medium unless otherwise mentioned. The proteins were desalted by gel filtration through a Sephadex G-50 column $(25 \times 30 \mathrm{~cm})$. The proteins were concentrated by pressure dialysis using an Amicon Pressure Dialyser fitted with a PM30 filter. This filter retains molecules larger than 30,000 dalton.

\subsection{Partial purification of the $\delta$-amino- levulinate synthesising enzymes by gel filtration on Sephacryl S-300}

A Sephacryl S-300 column $(5 \times 49 \mathrm{~cm})$ was equilibrated with elution medium. The stroma protein solution was adjusted to $25 \mathrm{~mm}-\mathrm{MgCl}_{2}$ and then loaded onto the column. The eluate was monitored for absorption of light at $280 \mathrm{~nm}$ and collected in $8 \mathrm{ml}$ fractions. Portions from the fractions were assayed with glutamate-U $-{ }^{14} \mathrm{C}$ for $\delta$-aminolevulinate synthesising activity. The active fractions were pooled and concentrated.

\subsection{Fractionation of the $\delta$-aminolevulinate synthesising enzymes by affinity chroma- tography on heme-Sepharose, Blue Sepha- rose and Matrex Gel Red $A$}

The heme-Sepharose column $(1 \times 4 \mathrm{~cm})$, the Blue Sepharose column $(1 \times 6 \mathrm{~cm})$ and the Matrex Gel Red A column $(1 \times 6 \mathrm{~cm})$ were preequilibrated with the elution medium used for gel-filtration. Ten $\mathrm{ml}$ ( $30 \mathrm{mg}$ protein) of partially purified $\delta$-aminolevulinate synthesising enzymes were passed through each column. The columns were washed with the elution medium until no further proteins eluted. The run-off fraction (proteins that do not bind) was concentrated. Bound proteins were eluted from the hemeSepharose column with $0.3 \mathrm{M}-\mathrm{NaCl}$ in the elution medium and from the other two columns with $1 \mathrm{M}-\mathrm{NaCl}$ in the elution medium. Each of these fractions was desalted and concentrated to $10 \mathrm{ml}$. The affinity columns were regenerated by the following procedures. The heme-Sepharose column was washed three times, alternately with $96 \%$ acetic acid and elution medium. The Blue Sepharose column was washed with $0.5 \mathrm{M}-\mathrm{NaCl}$ in $0.1 \mathrm{M}-\mathrm{Na}$ acetate $\mathrm{pH} 4.5$ and thereafter with elution medium. Matrex Gel Red A was washed with $7 \mathrm{~m}$-urea in $0.5 \mathrm{~m}-\mathrm{NaOH}$ and with elution medium. 


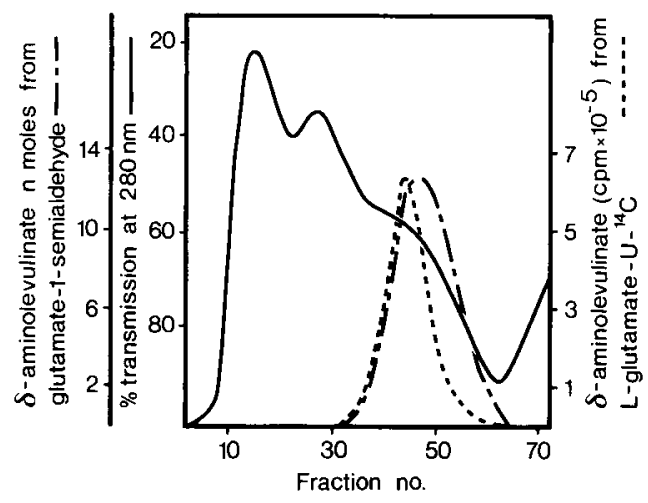

Figure 1. Elution pattern of $\delta$-aminolevulinate synthesising activity from a Sephacryl S-300 column.

\subsection{Serial affinity chromatography of the partially purified $\delta$-aminolevulinate syn- thesising proteins}

Stroma proteins obtained from isolated plastids were fractionated on a Sephacryl S-300 column as described in section 2.7. When the fractions that were known to contain the $\delta$ aminolevulinate synthesising proteins began to appear (cf. Figure 1), the eluate of the S-300 column was passed through the following columns in series: Blue Sepharose $(2.5 \times 8.5$ $\mathrm{cm})$, Matrex Gel Red A $(1 \times 6 \mathrm{~cm})$ and hemeSepharose $(2 \times 10 \mathrm{~cm})$. The final eluate from the column series was scanned for absorption of light at $280 \mathrm{~nm}$ and the proteins (run-off proteins) were collected and concentrated to 10 $\mathrm{ml}$. After the $\delta$-aminolevulinate synthesising proteins were completely eluted from the S-300 column it was disconnected from the series of subsequent columns. The elution medium was then pumped directly through the Blue Sepharose column until no further run-off proteins eluted from the heme-Sepharose column. The run-off protein fraction was concentrated to 10 $\mathrm{ml}$. Proteins bound to the Blue Sepharose column and the heme-Sepharose column were eluted with $1 \mathrm{~m}-\mathrm{NaCl}$ in the elution medium. These fractions were then desalted. After desalting, the protein fraction binding to hemeSepharose was concentrated to $10 \mathrm{ml}$. The desalted proteins binding to Blue Sepharose were passed through a small heme-Sepharose column $(1 \times 4 \mathrm{~cm})$ and the fraction not binding to the heme column was collected and concentrated to $10 \mathrm{ml}$. The procedure is illustrated in Figure 2.

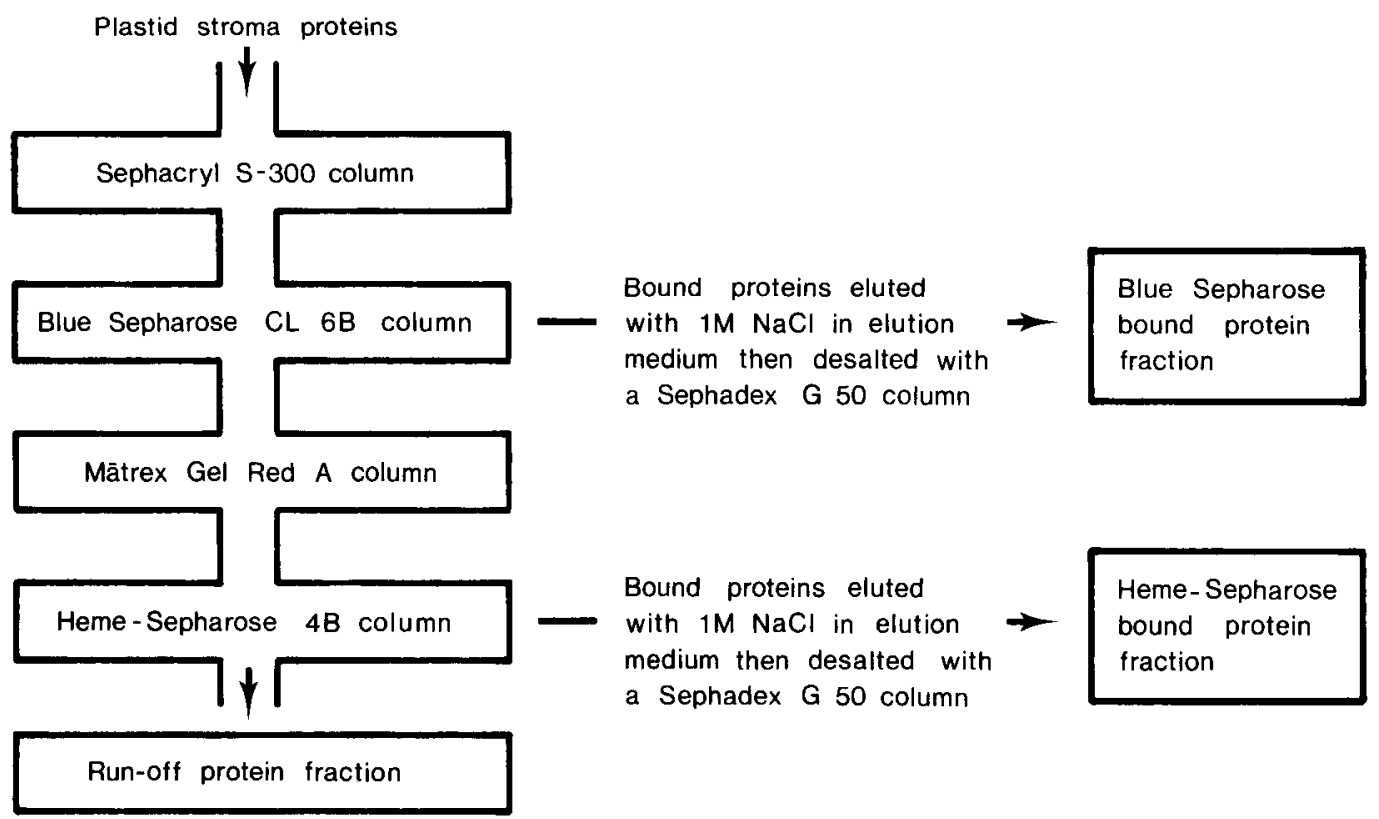

Figure 2. Diagram illustrating partial purification and serial affinity chromatography of the $\delta$-aminolevulinate synthesising enzymes. 


\subsection{Assay for $\delta$-aminolevulinate synthesising activity with radioactive or unlabelled glutamate}

The following standard assay was used unless otherwise stated: To the enzyme in $2 \mathrm{ml}$ of elution medium were added $2 \mu$ mole of NADPH, $1 \mu$ mole of ATP and 200 nmoles of L-glutamate or $2.5 \mu \mathrm{Ci}$ L-glutamate $\mathrm{U}-{ }^{14} \mathrm{C}$. The incubation was for $20 \mathrm{~min}$ at $27^{\circ} \mathrm{C}$.

\subsection{Glutamate-l-semialdehyde aminotrans- ferase assay}

The assay was carried out in $1 \mathrm{ml}$ of elution medium containing approximately $2 \mathrm{~mm}$-glutamate-l-semialdehyde and $100 \mu \mathrm{g}$ of protein. The reaction proceeded for 20 minutes at $27^{\circ} \mathrm{C}$ and was stopped by adding $20 \mu \mathrm{l}$ of $70 \%$ perchloric acid. After removal of the precipitated protein by centrifugation, the supernatant was adjusted to pH 6.9 and incubated with $100 \mu \mathrm{l}$ of ethyl acetoacetate, at $100^{\circ} \mathrm{C}$ for 20 minutes. The pyrrole formed was treated with modified Ehrlich's reagent (9) and the absorption at 525 and $553 \mathrm{~nm}$ was measured after 20 minutes. The amount of $\delta$-aminolevulinate was estimated using $\varepsilon_{\mathrm{mM}} 553 \mathrm{~nm}$ of $58 \mathrm{l} \cdot \mathrm{mmole}^{-1}(9)$.

\subsection{Determination of radioactive $\delta$-amino- levulinate}

The assay mixture was cooled on ice, $100 \mu \mathrm{g}$ of $\delta$-aminolevulinate hydrochloride added as carrier and proteins precipitated by the addition of $40 \mu \mathrm{l}$ of $70 \%$ perchloric acid. After removal of the precipitated protein by centrifugation, the sample was loaded onto a Dowex 50W X 8 column $(0.6 \times 2 \mathrm{~cm})$ which was prewashed with $2 \mathrm{ml}$ of Na-citrate buffer (pH 3.1, 0.2 $\mathrm{M}-\mathrm{Na}^{+}$). After loading, the column was washed again with $2 \mathrm{ml}$ of the pH $3.1 \mathrm{Na}$-citrate buffer. The $\delta$ aminolevulinate which had adsorbed to the column was eluted with $5 \mathrm{ml}$ of Na-citrate buffer $\left(\mathrm{pH} 5.1,0.2 \mathrm{M}-\mathrm{Na}^{+}\right)$. The $\delta$-aminolevulinate was converted to a pyrrole with ethyl acetoacetate and the pyrrole purified by thin layer chromatography as described previously $(6,13)$. The purified pyrrole was eluted from the chromatogram and analysed for the recovery of carrier. The radioactivity was measured and corrected for the recovery. This procedure is modified from the one described previously (13). It will not discriminate between ${ }^{14} \mathrm{C}$-glutamate-l-semialdehyde and ${ }^{14} \mathrm{C}$ - $\delta$-aminolevulinate although recoveries of the aldehyde may be low due to the absence of added cold carrier.

\subsection{Assay for $\delta$-aminolevulinate formed from unlabelled glutamate}

Samples were prepared and loaded onto Dowex columns as described in 2.12. The fraction eluted at $\mathrm{pH} 5.1$, which contained $\delta$ aminolevulinate (and also glutamate-l-semialdehyde if present), was adjusted to $\mathrm{pH}$ 6.9. After the addition of $100 \mu \mathrm{l}$ of ethyl acetoacetate, pyrrole was formed by heating at $100^{\circ} \mathrm{C}$ for 20 minutes. The samples were cooled and adjusted to $\mathrm{pH} 7.5$ and the ethyl acetoacetate removed by three extractions with chloroform. The samples were adjusted to $\mathrm{pH} 3.8$ and pyrrole obtained by three extractions with ether. After addition to the ether of one drop of $25 \%$ ammonia it was evaporated to dryness. Equal volumes of distilled water and modified Ehrlich's reagent (9) were added. After 20 minutes, the absorption at 525 and $553 \mathrm{~nm}$ was determined with a Zeiss PMQ spectrophotometer or the absorption spectra scanned using an Aminco DW2A spectrophotometer. The amount of $\delta$-aminolevulinate was estimated using a $\varepsilon_{\mathrm{mM}} 553 \mathrm{~nm}$ of 58 (9). Under these conditions, glutamate-l-semialdehyde also forms a pyrrole which gives a pink colour with Ehrlich's reagent. But this pyrrole has a $\varepsilon_{\mathrm{mM}} 553 \mathrm{~nm}$ at least one order of magnitude smaller and will not interfere with $\delta$-aminolevulinate estimations.

\subsection{Separation of glutamate, glutamate-I- semialdehyde and $\delta$-aminolevulinate by cation exchange chromatography on Do- wex $50 \mathrm{~W} \times 8$}

In order to determine the presence of glutamate-1-semialdehyde in incubated samples it was necessary to separate the aldehyde from $\delta$-aminolevulinate and NADPH. This was done by cation exchange chromatography on Dowex 50W X 8 (200-400 mesh) (14). A Dowex column $(0.6 \times 2$ $\mathrm{cm})$ was washed with $2 \mathrm{ml}$ of $1 \mathrm{M}-\mathrm{NaOH}$ and equilibrated with $2 \mathrm{ml} \mathrm{Na-citrate} \mathrm{buffer}(0.2 \mathrm{~m}$ $\mathrm{Na}^{+}$) pH 3.1. After deproteinising with perchlo- 
ric acid the sample ( $2 \mathrm{ml}$ ) was adjusted to $\mathrm{pH} 1.9$ with $5 \mathrm{~m}-\mathrm{KOH}$ and the precipated $\mathrm{KClO}_{4}$ removed by centrifugation. The supernatant was loaded onto the cation exchange column. The column was then washed sequentially with sodium citrate buffers $\left(0.2 \mathrm{M}-\mathrm{Na}^{+}\right)$at $\mathrm{pH} 3.1(3$ $\mathrm{ml}), 3.6(3 \mathrm{ml}), 4.1(1 \mathrm{ml}), 4.6(2 \mathrm{ml}+1 \mathrm{ml})$ and $5.1(3 \mathrm{ml})$. In this procedure NADPH does not bind to Dowex and glutamate elutes in the fractions at $\mathrm{pH} 3.1$ and 3.6. Most of the glutamate-l-semialdehyde elutes in the fractions at $\mathrm{pH}$ 4.1 and 4.6 and most of the $\delta$-aminolevulinate in the $\mathrm{pH} 5.1$ fraction.

The relative concentrations of glutamate-1semialdehyde present in fractions were estimated by incubating the fractions with glutamate-lsemialdehyde aminotransferase for 20 minutes at $27^{\circ} \mathrm{C}$, after adjusting the $\mathrm{pH}$ to 8.0 with phosphate buffer. The $\delta$-aminolevulinate from the $\mathrm{pH} 5.1$ fraction and that formed from glutamate-1-semialdehyde were then estimated as described in 2.11 .

\subsection{High pressure liquid chromatographic separation of glutamate, glutamate-l- semialdehyde and $\delta$-aminolevulinate}

These compounds were separated on a reverse phase octadecyl silane column (Waters $\mu$ Bondapak $\mathrm{C}_{18}$ ) using a Waters $6000 \mathrm{~A}$ solvent delivery system. The mobile phase used was as follows: $50 \mathrm{~mm}-\mathrm{NaH}_{2} \mathrm{PO}_{4}$, adjusted to $\mathrm{pH} 3.0$ with phosphoric acid and made up to $5 \mathrm{~mm}$-sodium lauryl sulphonate and $1 \% \mathrm{t}$-amyl alcohol. This solvent system and column is a modified version of one reported by $\mathrm{H}_{\mathrm{ANCOCK}}$ et al. (10) for the separation of amino acids. Before injection of samples the column was washed with mobile phase for at least 30 minutes. It was important to equilibrate and operate at $20^{\circ} \mathrm{C}$.

\subsection{Preparation of samples and high pressure liquid chromatography}

After incubation the samples were cooled on ice and carrier glutamate-l-semialdehyde and $\delta$ aminolevulinate added to give a concentration of $3 \mathrm{~mm}$ of each. Proteins were precipitated by the addition of $20 \mu \mathrm{l}$ of $70 \%$ perchloric acid per $\mathrm{ml}$ of sample. After removal of proteins, the $\mathrm{pH}$ of the supernatant was adjusted to 3.0 with $5 \mathrm{M}$ -
$\mathrm{KOH}$ and the precipiated $\mathrm{KClO}_{4}$ removed by centrifugation. A portion of the supernatant (20 ul) was injected into the high pressure liquid chromatograph and collection of $2 \mathrm{ml}$ fractions started immediately. From each fraction one $\mathrm{ml}$ was used to measure radioactivity, and from appropriate fractions, $0.5 \mathrm{ml}$ was assayed for glutamate-l-semialdehyde, using glutamate-lsemialdehyde aminotransferase as in 2.11 except that the $\mathrm{pH}$ was 8.0 , and $0.5 \mathrm{ml}$ was used for $\delta$ aminolevulinate determination.

\subsection{Glutamine synthetase (5-glutamyl kinase) and 1-glutamyl kinase assays}

These activities were assayed in elution medium (pH 7.9) containing $25 \mathrm{~mm}$ L-glutamate, $5 \mathrm{~mm}$ ATP, $12.5 \mathrm{~mm}-\mathrm{MgCl}_{2}$ and $50 \mathrm{~mm} \mathrm{NH}_{2} \mathrm{OH}$. Incubation was for 20 minutes at $27^{\circ} \mathrm{C}$. After incubation glutamate hydroxamates formed were determined according to Hestrin (12). The volume was adjusted to $2.0 \mathrm{ml}$ with distilled water and $0.5 \mathrm{ml}$ of $10 \% \mathrm{FeCl}_{3}$, in $0.1 \mathrm{M}-\mathrm{HCl}$ and $3.3 \%$ trichloracetic acid, was added. The $\mathrm{pH}$ was then adjusted to $1.2 \pm 0.2$ with $12 \% \mathrm{HCl}$, the solution centrifuged and the absorption at $540 \mathrm{~nm}$ measured against a control which had been incubated in the absence of enzyme.

1-Glutamyl kinase activity was measured in the presence and absence of $10 \mathrm{~mm}$ L-methionine-DL-sulphoximine, a strong inhibitor of pea leaf glutamine synthetase (19) and other 5glutamyl kinase activities $(1,18)$.

\subsection{Assay for $\delta$-aminolevulinate dehydratase and porphobilinogen deaminase}

These activities were assayed in $1 \mathrm{ml}$ of $0.3 \mathrm{M}$ glycerol, 0.1 m-Tricine- $\mathrm{NaOH}(\mathrm{pH}$ 8) with $10 \mathrm{~mm}-\delta$-aminolevulinate for the dehydratase and $100 \mu \mathrm{g}$ of porphobilinogen for the deaminase. After incubation for $20 \mathrm{~min}$ at $27^{\circ} \mathrm{C}$ the samples were deproteinised by adding $20 \mu \mathrm{l}$ of $70 \%$ perchloric acid and centrifugation. Porphobilinogen formed in the dehydratase assay was determined with modified Ehrlich's reagent (9). Uroporphyrinogen formed in the deaminase assay was converted to uroporphyrin when the acidified samples were left for $15 \mathrm{~min}$ at room temperature. Uroporphyrin was determined by spectrophotometry using $\varepsilon_{\mathrm{mM}} 406=541$ a value determined in $0.5 \mathrm{~N} \mathrm{HCl}(2)$. 


\section{RESULTS AND DISCUSSION}

3.1. Partial purification of the $\delta$-aminolevulinate synthesising enzymes from the plastid stroma by gel-filtration on Sephacryl S-300

The $\delta$-aminolevulinate synthesising proteins present in the plastid stroma preparation were partially purified by gel-filtration. Three main ultraviolet light absorbing peaks were eluted from the Sephacryl S-300 column (Figure 1). The first peak contained membrane proteins and was green. The later half of the second band and the third band were able to convert glutamate and glutamate-1-semialdehyde to $\delta$-aminolevulinate.

\subsection{Affinity chromatography of the partially} purified $\delta$-aminolevulinate synthesising enzymes on heme-Sepharose and separation into two fractions

Heme strongly inhibits $\delta$-aminolevulinate synthesis from glutamate (8).

Advantage was taken of this fact and a hemeSepharose column prepared to which the $\delta$ aminolevulinate synthesising enzymes or a component thereof could be bound. As shown in Table I, the heme-Sepharose column binds a small amount of protein when the partially purified $\delta$-aminolevulinate synthesising enzymes were passed through. Neither the bound protein fraction nor the proteins which passed through the column and contained the glutamate-Isemialdehyde aminotransferase activity were able to convert large amounts of glutamate to $\delta$ aminolevulinate. However, a 15 fold stimulation of $\delta$-aminolevulinate synthesis from glutamate was seen when these two fractions were combined. We conclude that a protein binding to the heme-Sepharose column is required for $\delta$ aminolevulinate synthesis. The retained protein is most likely the component of the $\delta$-aminolevulinate synthesising system which is regulated by heme.

\subsection{Affinity chromatography of the partially purified $\delta$-aminolevulinate synthesising en- zymes on Blue Sepharose CL 6B and Matrex Gel Red A}

Blue Sepharose and Matrex Gel were used as affinity material to separate the partially purified $\delta$-aminolevulinate synthesising enzymes. As with the heme-Sepharose chromatography, glutamate-l-semialdehyde aminotransferase activity was not retained by Blue Sepharose (Table I). The protein fractions separated by either the Blue Sepharose or the Matrex Gel synthesised little $\delta$ aminolevulinate from glutamate (Table I). When

Table I

Reconstitution of the $\delta$-aminolevulinate synthesising activity by combining the two fractions from the partially purified $\delta$-aminolevulinate synthesising enzymes separated on three different affinity columns.

ALA $=\delta$-aminolevulinate. $-=$ not done.

\begin{tabular}{llcr}
\hline $\begin{array}{l}\text { Affinity } \\
\text { column }\end{array}$ & $\begin{array}{l}\text { Protein } \\
\text { fraction (mg) }\end{array}$ & $\begin{array}{c}\text { Aminotransferase activity } \\
\text { (nmole ALA formed) }\end{array}$ & $\begin{array}{r}\text { cpm incorporated } \\
\text { into ALA }\end{array}$ \\
\hline Heme-Sepharose & $\begin{array}{l}\text { run-off }(1.380) \\
\text { bound }(0.044)\end{array}$ & 34 & 6.900 \\
& run-off + bound & 1.6 & 2,200 \\
Blue Sepharose & run-off (1.050) & - & 141.000 \\
& bound $(0.295)$ & 21 & 1.200 \\
& run-off + bound & trace & 2.200 \\
Matrex Gel Red A & run-off $(0.250)$ & - & 401,000 \\
& bound $(0.780)$ & - & 1,100 \\
& run-off + bound & - & 1.700 \\
\hline
\end{tabular}




\section{Table II}

Synthesis of $\delta$-aminolevulinate by protein fractions obtained from heme-Sepharose and Blue Sepharose affinity chromatography of partially purified $\delta$-aminolevulinate synthesising enzymes.

Protein concentrations used in the assays are as follows: Heme-Sepharose bound fraction $(0.044 \mathrm{mg})$, hemeSepharose run-off fraction $(1.38 \mathrm{mg})$, Blue Sepharose bound fraction $(0.295 \mathrm{mg})$, Blue Sepharose run-off fraction $(1.05 \mathrm{mg})$ and purified glutamate-l-semialdehyde aminotransferase $(1.2 \mathrm{mg})$.

\begin{tabular}{|c|c|c|}
\hline Assay & & $\begin{array}{l}\text { cpm incorporated into } \\
\delta \text {-aminolevulinate }\end{array}$ \\
\hline $\begin{array}{l}\text { Heme-Sepharose } \\
\text { run-off }\end{array}$ & $\begin{array}{l}+ \text { Heme-Sepharose } \\
\text { bound }\end{array}$ & 141,000 \\
\hline $\begin{array}{l}\text { Blue Sepharose } \\
\text { run-off }\end{array}$ & $\begin{array}{l}\text { Blue Sepharose } \\
\text { bound }\end{array}$ & 401,000 \\
\hline $\begin{array}{l}\text { Heme-Sepharose } \\
\text { run off }\end{array}$ & $\begin{array}{l}\text { Blue Sepharose } \\
\text { bound }\end{array}$ & 22,000 \\
\hline $\begin{array}{l}\text { Heme-Sepharose } \\
\text { bound }\end{array}$ & $\begin{array}{l}\text { Blue Sepharose } \\
\text { run-off }\end{array}$ & 3,300 \\
\hline $\begin{array}{l}\text { Heme-Sepharose } \\
\text { bound }\end{array}$ & + Aminotransferase & 2,100 \\
\hline $\begin{array}{l}\text { Blue Sepharose } \\
\text { bound }\end{array}$ & + Aminotransferase & 3,500 \\
\hline $\begin{array}{l}\text { Blue Sepharose bo } \\
\text { bound }+ \text { Aminots }\end{array}$ & $\begin{array}{l}\text { und }+ \text { Heme-Sepharose } \\
\text { ransferase }\end{array}$ & 72,100 \\
\hline
\end{tabular}

the two protein fractions separated on the Blue Sepharose column were combined, a 113 fold stimulation of $\delta$-aminolevulinate synthesis from glutamate was observed. Reconstituting the two protein fractions separable on the Matrex Gel column yielded a 10 fold stimulation. Affinity chromatography with Blue Sepharose and Matrex Gel, like that with heme-Sepharose, can separate the $\delta$-aminolevulinate synthesising enzymes into two fractions which upon reconstitution actively convert glutamate into $\delta$-aminolevulinate.

\section{Table III}

Synthesis of $\delta$-aminolevulinate from glutamate by protein fractions obtained from serial affinity chromatography of partially purified $\delta$-aminolevulinate synthesising enzymes.

Assay with

nmoles of $\delta$-aminolevulinate formed

\begin{tabular}{lcc} 
& - Levulinate & + 5mm-Levulinate \\
\hline 1. Run-off proteins $(1.7 \mathrm{mg})$ & 0 & 0 \\
2. Heme-Sepharose bound proteins $(0.36 \mathrm{mg})$ & 0 & 0 \\
3. Blue Sepharose bound proteins $(1.1 \mathrm{mg})$ & 0 & 0 \\
$4 . \quad 1 .+2$. & 0 & 0 \\
$5 . \quad 1 .+3$. & 0 & 0 \\
$6 . \quad 2 .+3$. & trace & trace \\
$7 . \quad 1 .+2 .+3$. & 7.4 & 17 \\
\hline
\end{tabular}




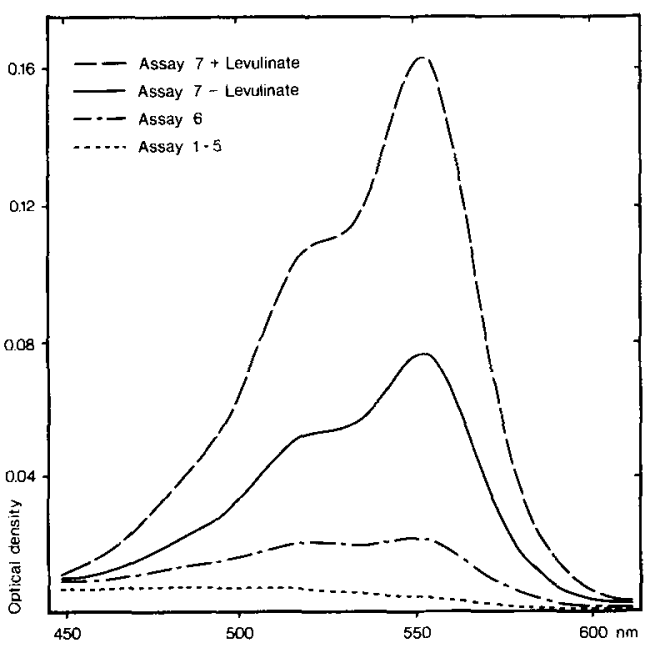

Figure 3. Formation of $\delta$-aminolevulinate from cold glutamate. Absorption spectra of Ehrlich's reagent treated pyrroles derived from the products formed in the assays of Table III. $\delta$-Aminolevulinate is formed in assay 7 in larger amounts in the presence of levulinate than its absence.

\subsection{Experiments combining fractions from the Blue Sepharose column with fractions from the heme-Sepharose column}

Assays for $\delta$-aminolevulinate synthesis were performed after combining fractions from the Blue Sepharose column and the heme-Sepharose column. Table II shows that in no case could a fraction from Blue Sepharose be combined with a fraction from heme-Sepharose to give activities comparable with those obtained by combining fractions from the same column. Even though aminotransferase activity was present in the fractions not bound to the columns, purified aminotransferase could not replace the run-off fractions in reconstitution experiments with a bound fraction. However, aminotransferase was able to substitute for the run-off fractions when combined with both of the bound fractions.

It is concluded that the two columns segregate the components of the $\delta$-aminolevulinate synthesising enzymes differently and that there are more than two components required for the conversion of glutamate into $\delta$-aminolevulinate. In addition the two columns retain different proteins which together with purified glutamatel-semialdehyde aminotransferase can synthesize $\delta$-aminolevulinate from glutamate.

\subsection{Requirement of three different proteins for the synthesis of $\delta$-aminolevulinate from glutamate}

Separation of the $\delta$-aminolevulinate synthesising enzymes into three separate protein fractions was achieved by serial affinity chromatography using Blue Sepharose CL 6B, Matrex Gel Red $\mathrm{A}$ and heme-Sepharose $4 \mathrm{~B}$ as described in

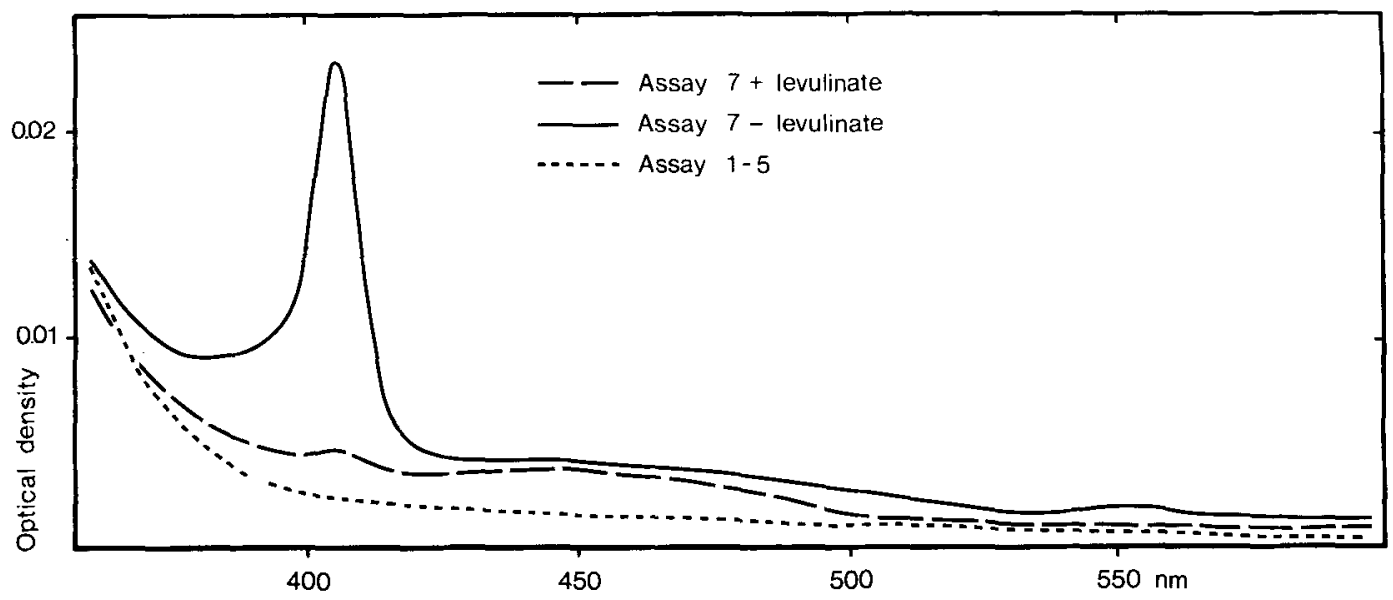

Figure 4. Formation of uroporphyrin from glutamate by combining the three protein fractions isolated by serial affinity chromatography.

The spectra were recorded from the assays given in Table III. Assay No. 7 without levulinate gives a spectrum characteristic for uroporphyrin which is largely absent when levulinate is present. 
Method section 2.9. (cf. Figure 2). These three protein fractions, one bound to Blue Sepharose, one bound to heme-Sepharose and one which did not bind to the three columns were tested individually and in combination for $\delta$-aminolevulinate synthesis from glutamate.

In the experiments using unlabelled glutamate (Table III, Figure 3), all three protein fractions were needed for $\delta$-aminolevulinate synthesis from glutamate. When the three fractions were incubated together, twice as much $\delta$-aminolevulinate was formed in the presence of levulinate than in its absence. Furthermore, in the absence of levulinate an additional product was formed which after perchloric acid treatment fluoresced red under ultraviolet light and had an absorption spectrum characteristic of uroporphyrin (Figure 4). It appears that glutamate was converted into uroporphyrinogen in addition to $\delta$-aminolevulinate in the absence of levulinate. An increased $\delta$ aminolevulinate accumulation in the presence of levulinate is due to the inhibition of the $\delta$ aminolevulinate dehydratase. When the Blue Sepharose bound protein fraction and the hemeSepharose bound protein fraction were combined
(Assay 6 in Table III), glutamate was converted into a product which after pyrrole formation, gave a weak Ehrlich reaction (Figure 3).

In similar experiments using radioactive glutamate, the requirement of all three protein fractions for $\delta$-aminolevulinate synthesis from glutamate was confirmed (Table IV). Radioactive $\delta$-aminolevulinate formation was again increased in the presence of levulinate. The run-off protein fraction, which has all the aminotransferase activity (Table V), could be replaced by purified aminotransferase. Therefore, the product formed by combining the protein fractions bound to Blue Sepharose and heme-Sepharose is expected to be glutamate-1-semialdehyde (Assay 6 , Table IV). This is confirmed by experiments described in the following sections.

Significant $\delta$-aminolevulinate dehydratase and porphobilinogen deaminase activities were found in the run-off protein fraction (Table $V$ ). These results explain the increased $\delta$-aminolevulinate formation in the presence of levulinate (Assay 7 , Tables III and IV) and the accumulation of uroporphyrinogen in the absence of levulinate (Figure 4).

\section{Table IV}

Synthesis of $\delta$-aminolevulinate from L-glutamate-U-14 C by protein fractions obtained from serial affinity chromatography of partially purified $\delta$-aminolevulinate synthesising enzymes.

\begin{tabular}{|c|c|c|c|c|}
\hline \multirow{3}{*}{ Assay } & \multicolumn{4}{|c|}{$\begin{array}{l}\text { cpm incorporated into } \delta \text {-aminolevulinate } \\
\text { (in sample } 6 \text {, glutamate-l-semialdehyde) }\end{array}$} \\
\hline & \multicolumn{2}{|c|}{ I } & \multirow{2}{*}{$\begin{array}{c}\text { II } \\
+ \text { Lev }\end{array}$} & \multirow{2}{*}{$\begin{aligned} & \text { III } \\
+ & \text { Lev }\end{aligned}$} \\
\hline & - Lev & $+\mathrm{Lev}$ & & \\
\hline 1. Run-off proteins & 700 & 900 & 3,100 & 2.300 \\
\hline 2. Heme-Sepharose bound proteins & 1,100 & 1,300 & 1.400 & 1,800 \\
\hline 3. Blue Sepharose bound proteins & 1,800 & 2,100 & 3,500 & 4,900 \\
\hline 4. $\quad 1+2$ & 1,300 & 800 & 1,800 & 1,500 \\
\hline $1+3$ & 4.000 & 5,300 & 6,400 & 16,800 \\
\hline $2+3$ & 505,000 & 740,000 & 640,000 & 570.000 \\
\hline $1+2+3$ & $1,120,000$ & $1,980,000$ & $2,620,000$ & $2.210,000$ \\
\hline $2+3+$ aminotransferase & - & - & $2,920,000$ & $1,520,000$ \\
\hline
\end{tabular}

In experiment I, proteins used for samples 1,2 and 3 were $1.7 \mathrm{mg}, 0.36 \mathrm{mg}$ and $1.1 \mathrm{mg}$. In experiment II, proteins used for samples 1,2 and 3 were $1.86 \mathrm{mg}, 0.24 \mathrm{mg}$ and $1.05 \mathrm{mg}$. In experiment III, proteins used for samples 1,2 and 3 were $1.26 \mathrm{mg}, 0.26 \mathrm{mg}$ and $0.88 \mathrm{mg}$. Aminotransferase was purified as described in section $2.5,0.62 \mathrm{mg}$ was used. Lev $=5 \mathrm{~mm}$-levulinate. $-=$ not done. 
Table V

Glutamate-l-semialdehyde aminotransferase, $\delta$-aminolevulinate dehydratase and porphobilinogen deaminase activities associated with the three protein fractions obtained by serial affinity chromatography.

\begin{tabular}{lccc}
\hline Protein fraction & $\begin{array}{c}\text { Glutamate-l-semialdehyde } \\
\text { aminotransferase }\end{array}$ & ALA-dehydratase & PBG-deaminase \\
\hline $\begin{array}{l}\text { Run-off proteins } \\
\begin{array}{l}\text { Heme-Sepharose } \\
\text { bound proteins }\end{array}\end{array}$ & 160 & 100 & 4.7 \\
$\begin{array}{l}\text { Blue Sepharose } \\
\text { bound proteins }\end{array}$ & 7.2 & 13 & 0.5 \\
\hline
\end{tabular}

Glutamate-1-semialdehyde aminotransferase activity is given in nmoles ALA $\cdot \mathrm{mg}$ protein ${ }^{-1} .20 \mathrm{~min}^{-1}$. ALA. dehydratase activity is given in nmoles PBG $\cdot \mathrm{mg}$ protein ${ }^{-1} \cdot 20 \mathrm{~min}^{-1}$. PBG-deaminase activity is given in nmoles of uroporphyrin $\cdot \mathrm{mg}$ protein ${ }^{-1} \cdot 20 \mathrm{~min}^{-1} . \mathrm{ALA}=\delta$-aminolevulinate. $\mathrm{PBG}=$ porphobilinogen .

\subsection{Glutamate-l-semialdehyde as an intermedi- ate in $\delta$-aminolevulinate synthesis from glutamate}

In order to demonstrate that glutamate-1semialdehyde is an intermediate in $\delta$-aminolevu-

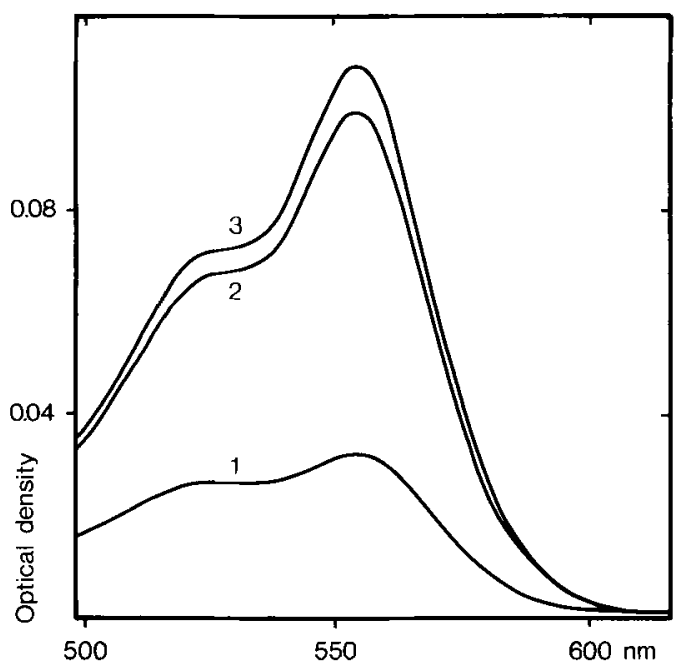

Figure 5. Enzymic synthesis of glutamate-l-semialdehyde from glutamate.

Absorption spectra are given for the pyrrole derivatives of the assay products after treatment with Ehrlich's reagent. Glutamate was incubated with the heme-Sepharose bound protein fraction and Blue Sepharose bound protein fraction. The incubation mixture was deproteinised and incubated with elution medium as control (1), with purified aminotransferase (2) and with the run-off fraction (3). linate synthesis, the following experiment was carried out. Blue Sepharose bound fraction (1.1 $\mathrm{mg}$ protein) and heme-Sepharose bound fraction $(0.36 \mathrm{mg}$ protein) were incubated with $0.1 \mathrm{~mm}$ glutamate, $1 \mathrm{~mm}-\mathrm{NADPH}, 0.5 \mathrm{~mm}-\mathrm{ATP} 25 \mathrm{~mm}-$ $\mathrm{MgCl}_{2}$ and $5 \mathrm{~mm}-\mathrm{Na}-\mathrm{levulinate}$ in $2 \mathrm{ml}$ of elution medium for 20 minutes at $27^{\circ} \mathrm{C}$. The reaction was stopped by adding $40 \mu \mathrm{l}$ of cold perchloric acid $(70 \%)$. The precipitated proteins were removed by centrifugation and the supernatant was carefully adjusted to $\mathrm{pH} 8.0$ using $1 \mathrm{M}$ $\mathrm{NaOH}$ and $0.5 \mathrm{M}-\mathrm{Na}_{3} \mathrm{PO}_{4}$. The supernatant was then incubated for another 20 minutes at $27^{\circ} \mathrm{C}$ with either purified glutamate-l-semialdehyde aminotransferase $(0.6 \mathrm{mg})$ or the run-off fraction (1.7 mg protein). The control was performed by adding elution medium prior to the second incubation. Figure 5 illustrates that the Blue Sepharose bound fraction and the heme-Sepharose bound fraction together make a product which can be converted into $\delta$-aminolevulinate either by glutamate l-semialdehyde aminotransferase or the run-off protein fraction.

\subsection{Identification of the intermediate as gluta- mate-l-semialdehyde by cation exchange chromatography on Dowex $50 \mathrm{~W} \times 8$}

As has been previously shown, glutamate-1semialdehyde, glutamate and $\delta$-aminolevulinate bind to the cation exchanger Dowex 50W $\mathrm{X} 8$ equilibrated to $\mathrm{pH} 3.1$ (14). These amino- 


\section{Table VI}

Identification of enzymically synthesised glutamatel-semialdehyde by purification on Dowex 50W X 8.

The protein fractions bound to heme-Sepharose $(0.52$ $\mathrm{mg})$ and to Blue Sepharose $(1.75 \mathrm{mg})$ were incubated with unlabelled glutamate as given in section 2.9 except that the assay was carried out at $\mathrm{pH} 7.9$ in 4 $\mathrm{ml}$. The sample was then divided in two and fractionated on two cation exchange columns and pairs of homologous samples were collected and combined. These samples were used for $\delta$-aminolevulinate determination before and after incubation with purified glutamate-l-semialdehyde aminotransferase.

\begin{tabular}{lccc}
\hline & & \multicolumn{2}{c}{$\begin{array}{c}\text { nmoles of } \delta \text {-aminolevulinate } \\
\text { in each fraction }\end{array}$} \\
\cline { 3 - 4 } $\begin{array}{l}\mathrm{pH} \text { of } \\
\text { eluting } \\
\text { buffer }\end{array}$ & $\begin{array}{c}\mathrm{ml} \text { of } \\
\text { fraction }\end{array}$ & $\begin{array}{c}\text { before } \\
\text { incubation with aminotransferase }\end{array}$ \\
\hline 3.1 & 3 & - & after \\
3.6 & 3 & - & - \\
4.1 & 1 & 0.8 & - \\
4.6 & 2 & 1.9 & 4.3 \\
4.6 & 1 & 0.7 & 7.4 \\
5.1 & 3 & 1.5 & - \\
\hline
\end{tabular}

compounds can be separated in this way from carboxylic acids such as $\alpha$-ketoglutarate and 4.5dioxovalerate which do not bind. From the column, glutamate can be eluted at $\mathrm{pH} 3.6$,

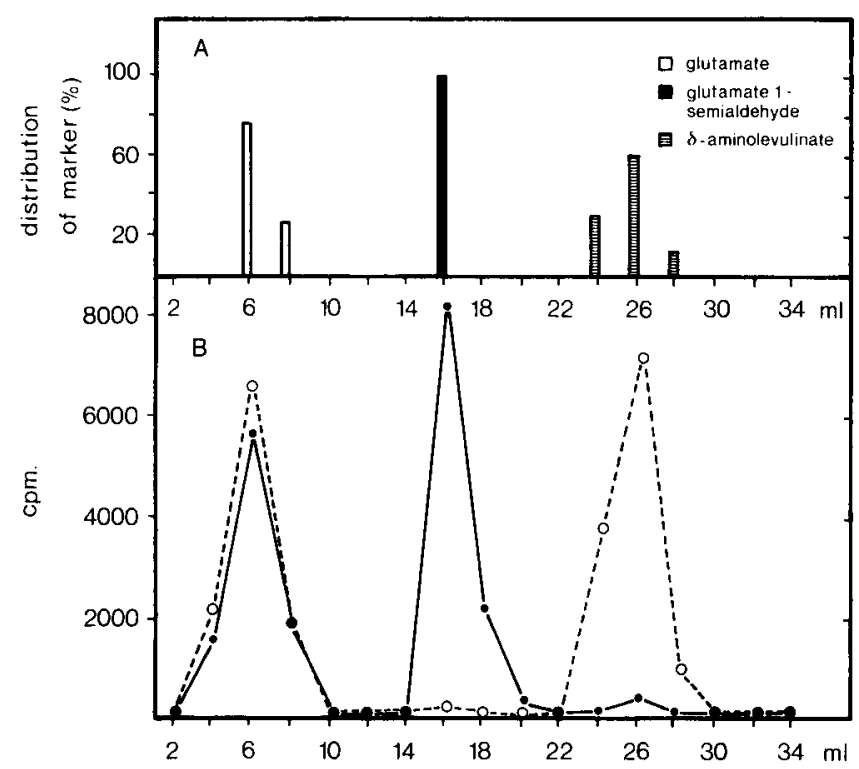

glutamate-l-semialdehyde at $\mathrm{pH} 4.1$ to 4.6 and $\delta$ aminolevulinate at $\mathrm{pH} 5.1$ (14). The intermediate formed from glutamate by incubation with a mixture of the protein fractions bound to Blue Sepharose and heme-Sepharose behaved like glutamate-1-semialdehyde on the Dowex column. The presence of glutamate-1-semialdehyde in the fractions eluted at $\mathrm{pH} 4.1$ and 4.6 where it should elute, was demonstrated by assaying for $\delta$-aminolevulinate directly and after incubation with purified glutamate-l-semialdehyde aminotransferase (Table VI). The traces of Ehrlich positive compounds present in the $\mathrm{pH} 4.1$ and 4.6 fractions before incubation with glutamate-1semialdehyde aminotransferase are probably due to pyrrole formed from glutamate-1-semialdehyde with ethyl acetoacetate. The trace of Ehrlich positive compound present in the $\mathrm{pH} 5.1$ fraction may be $\delta$-aminolevulinate formed by residual aminotransferase present in bound, protein fractions (Table I).

\subsection{The formation of ${ }^{14} \mathrm{C}$-glutamate-l-semial- dehyde by the protein fractions bound to Blue Sepharose and heme-Sepharose and its subsequent conversion to $\delta$-amino- levulinate by glutamate-l-semialdehyde aminotransferase}

In the high pressure liquid chromatographic system described in 2.15 and 2.16 , glutamate, glutamate-1-semialdehyde, and $\delta$-aminolevulinate could be completely separated from each other (Figure 6A). In this system, $\alpha$-ketoglutarate elutes before glutamate. The radioactive products formed by the protein fractions bound

Figure 6. High pressure liquid chromatography and the identification of radioactive glutamate-1-semialdehyde formed from L-glutamate-U $-14 \mathrm{C}$ by protein fractions bound to heme-Sepharose and Blue Sepharose.

$6 \mathrm{~A}$ presents the elution pattern of authentic glutamate-1-semialdehyde, $\delta$-aminolevulinate and $\mathrm{L}$ glutamate-U- ${ }^{14} \mathrm{C}$. $6 \mathrm{~B}$ shows the formation of radioactive glutamate-l-semialdehyde by incubating hemeSepharose bound and Blue Sepharose bound proteins (一). When the run-off protein fraction was incubated with the other two fractions radioactive $\delta$. aminolevulinate is formed (---). 
to Blue Sepharose and heme-Sepharose (Table IV, experiment II, assay 6) were separated into two main peaks (Figure 6B). The first peak (4-8 $\mathrm{ml}$ ) had the retention time of glutamate as determined by injection of a sample of authentic radioactive glutamate. This peak had $40 \%$ of the total radioactivity. The second radioactive peak (14-18 $\mathrm{ml}$ ) co-chromatographed with carrier glutamate-l-sermialdehyde. This peak contained $56 \%$ of the total radioactivity. Four per cent of the total radioactivity co-chromatographed with authentic $\delta$-aminolevulinate (in fraction 24-26 $\mathrm{ml}$ ). Comparing the above results with that of Table IV, experiment II, assay 6 , it is seen that only $12 \%$ of the incubated radioactive glutamate is recovered as glutamate-1-semialdehyde. This discrepancy may be explained by losses of radioactive semialdehyde during purification due to absence of cold carrier glutamate-l-semialdehyde.

It is concluded that the protein fractions bound to Blue Sepharose and heme-Sepharose convert $56 \%$ of the glutamate to glutamate 1-semialdehyde and only $4 \%$ to $\delta$-aminolevulinate. When the run-off protein fraction, which contains glutamate-1-semialdehyde aminotransferase, was added and incubated with the other two protein fractions (Table IV, experiment II, assay 7) $52 \%$ of the total radioactivity was present in $\delta$ aminolevulinate whereas only $1 \%$ appeared in glutamate-l-semialdehyde (Figure 6B) (compare Table IV, where $53 \%$ of the incubated radioactivity is found in ${ }^{14} \mathrm{C}$ - $\delta$-aminolevulinate). In these analyses all of the injected radioactivity was recovered in the three peaks.
The experiments described in sections 3.6, 3.7 and 3.8 reveal that glutamate-1-semialdehyde is an intermediate in the synthesis of $\delta$-aminolevulinate from glutamate and that glutamate-1semialdehyde aminotransferase is one of the three soluble proteins of the $\delta$-aminolevulinate synthesising enzyme system. Furthermore, aminotransferase is not necessary for the function of the other two enzymes.

\subsection{Evidence suggesting that the protein fraction bound to the heme-Sepharose column contains glutamate-l-phosphate ki- nase activity}

A direct assay of glutamate-l-phosphate kinase activity by trapping the phosphate with hydroxylamine and measuring the red colour formed on addition of $\mathrm{FeCl}_{3}$ is complicated by the presence of glutamine synthetase and possibly other glutamyl kinases. Methionine sulphoximine $(10 \mathrm{~mm})$ strongly inhibits glutamine synthetase (19) and 5-glutamyl kinases $(1,18)$. The synthesis of $\delta$-aminolevulinate from glutamate by partially purified enzyme was not inhibited by this inhibitor. When the three protein fractions separated by serial affinity chromatography were assayed for their glutamine synthetase activity, most of the activity was found in the run-off protein fraction and the heme-Sepharose bound protein fraction (Table VII). In the presence of methionine sulphoximine, the heme-Sepharose bound fraction had five times higher activity per $\mathrm{mg}$ protein than that of the Blue Sepharose bound fraction. The

\section{Table VII}

Glutamate kinase activities associated with the three protein fractions obtained by serial affinity chromatography.

\begin{tabular}{llcc}
\hline Assay with & Protein fraction & Hydroxamate formed & \\
& & OD 540nm & OD 540nm $\cdot \mathrm{mg}$ protein-1 \\
\hline & Heme-Sepharose bound & 0.25 & 4.8 \\
& Blue Sepharose bound & 0.13 & 0.70 \\
& Run-off protein & 0.52 & 2.0 \\
& & 0.21 & 0.80 \\
10mm-methionine & Heme-Sepharose bound & 0.14 & 0.15 \\
sulphoximine & Blue Sepharose bound & & \\
\hline
\end{tabular}


kinase activity found in the heme-Sepharose bound fraction is conceivably responsible for the synthesis of glutamate-1-phosphate and that associated with the run-off fraction is conceivably due to glutamine synthetase.

In another experiment, we attempted to use either the Biue Sepharose bound fraction or the heme-Sepharose bound fraction to convert glutamate in the presence of ATP and $\mathrm{Mg}^{2+}$ into a product which was then incubated in the presence of NADPH with appropriate fractions for enzymic formation of $\delta$-aminolevulinate. The heme-Sepharose bound fraction $(3 \mathrm{ml}, 1.56 \mathrm{mg}$ protein) and the Blue Sepharose bound fraction $(3 \mathrm{ml}, 5.28 \mathrm{mg}$ protein) were separately incubated with $0.5 \mathrm{~mm}-\mathrm{ATP}, 25 \mathrm{~mm}-\mathrm{MgCl}_{2}$ and $10 \mu \mathrm{Ci}$ of L-glutamate- $\mathrm{U}_{-}{ }^{14} \mathrm{C}$ for 20 minutes at $27^{\circ} \mathrm{C}$. The incubation mixtures were cooled on ice and filtered by pressure dialysis using a PM 10 filter which retains molecules larger than 10,000 dalton. The filtrate from the assay with the heme-Sepharose bound fraction was then incubated with $3 \mathrm{ml}$ of the Blue Sepharose bound fraction, $3 \mathrm{ml}$ of the run-off fraction $(7.56 \mathrm{mg}$ protein) and $1 \mathrm{~mm}-\mathrm{NADPH}$ for 20 minutes at $27{ }^{\circ} \mathrm{C}$ and analysed for ${ }^{14} \mathrm{C}$ - $\delta$-aminolevulinate. After purification $6800 \mathrm{cpm}$ were recovered in $\delta$-aminolevulinate. When the filtrate from the assay with the Blue Sepharose bound fraction was incubated with $3 \mathrm{ml}$ of heme-Sepharose bound fraction, $3 \mathrm{ml}$ of the run-off fraction and I mM-NADPH, only $1900 \mathrm{cpm}$ were recovered in $\delta$-aminolevulinate. These experiments indicate that the heme-Sepharose column binds an ATP utilising component of the $\delta$-aminolevulinate synthesising enzyme system which could be glutamate-l-phosphate kinase. The Blue Sepharose bound protein fraction then is likely to contain the glutamate-l-phosphate dehydrogenase. These indications will be followed up in further experiments.

\section{ACKNOWLEDGEMENTS}

The authors are most grateful to Ms WENAN L. WANG for technical assistance, Ms. HaNNE Them Nielsen for typing, Ms. Nina Rasmussen for drawing the figures and to DITER vON Wetrstein for constant encouragement and a critical reading of the manuscript.

\section{REFERENCES}

1. Adams, E. \& L. Frank: Metabolism of proline and hydroxyproline compounds. Ann. Rev. Biochem. 49, 1005-1062 (1980)

2. FALK, J. E.: Porphyrins and Metalloporphyrins, Elsevier. p 74 (1964)

3. Fluhr, R., E. Harel, S. Klejn \& E. Meller: Control of $\delta$-aminolevulinic acid and chlorophyll in greening maize leaves upon light dark transitions. Plant Physiol. 56, 497-501 (1975)

4. Ford, S. H. \& H. C. Friedmann: Formation of $\delta$-aminolevulinic acid from glutamic acid by a partially purified enzyme system from wheat leaves. Biochim. Biophys. Acta. 569, 153-158 (1979)

5. Gougr, S. P.: Light stimulated $\delta$-aminolevulinate accumulation in levulinate treated barley seedlings. Carlsberg Res. Commun. 43, 497508 (1978)

6. Gough, S. P. \& C. G. Kannangara: Synthesis of $\delta$-aminolevulinic acid by isolated plastids. Carlsberg Res. Commun. 41, 183-190 (1976)

7. Gough, S. P. \& C. G. Kannangara: Synthesis of $\delta$-aminolevulinate by a chloroplast stroma preparation from greening barley leaves. Carlsberg Res. Commun. 42, 459-464 (1977)

8. Gough, S. P. \& C. G. Kannangara: Biosynthesis of $\delta$-aminolevulinate in greening barley leaves III: The formation of $\delta$-aminolevulinate in tigrina mutants of barley. Carlsberg Res. Commun. 44, 403-416 (1979)

9. Granick, S., S. Sassa, J. L. Granick, R. D. Levene \& A. Kappas: Assays for porphyrins, $\delta$ aminolevulic acid dehydratase and porphobilinogen synthetase in microliter samples of whole blood: Application to metabolic defects involving the heme pathway. Proc. Nat. Acad. Sci. USA 69, 2381-2385 (1972)

10. HanCoCk, W. S., C. A. Bishop \& M. T. W. HEarn: The analysis of nanogram levels of free amino acids by reverse-phase high pressure liquid chromatography. Anal. Chem. 92, 170173 (1979)

11. Harel, E., \& S. Klein: Light dependent formation of $\delta$-aminolevulinic acid in etiolated leaves of higher plants. Biochem. Biophys. Res. Com. mun. 49, 364-370 (1972)

12. Hestrin, S.: The reaction of acetyl chloride and other carboxylic acid derivatives with hydroxylamine and its analytical application. J. Biol. Chem. 180, 249-261 (1949)

13. Kannangara, C. G. \& S. P. Gough: Synthesis of $\delta$-aminolevulinic acid and chlorophyll by isolated plastids. Carlsberg Res. Commun. 42, 441-458 (1977) 
14. Kannangara,C. G. \& S. P. Gough: Biosynthesis of $\delta$-aminolevulinate in greening barley leaves. Glutamate-1-semialdehyde aminotransferase. Carlsberg Res. Commun. 43. 185-194 (1978)

15. Kannangara, C. G., S. P. Gough \& D. von WETTSTEIN: Biosynthesis of $\delta$-aminolevulinate and chlorophyll and its genetic regulation. In: Development in Plant Biology 2. Chloroplast Development. Eds. G. Akoyunoglou \& J. H. Argyroudi-Akoyunoglou. Elsevier/North Holland. pp. 147-160 (1978)

16. Kannangara, C. G., S. P. Gough \& C. Girnth: $\delta$-aminolevulinate synthesis in greening barley. 2. Purification of enzymes. In Proc. Fifth International Congress in Photosynthesis 1980 ed. G. Akoyunoglou. In press.
17. Kannangara, C. G., S. P. Gough, B. Hansen, J. N. Rasmussen \& D. J. Simpson: A homogenizer with replaceable razor blades for bulk isolation of active barley plastids. Carlsberg Res. Commun. 42, 431-440 (1977)

18. Meister, A. \& S. S. TAte: Glutathione and $\gamma$ glutamyl compounds: biosynthesis and utilisation. Ann. Rev. Biochem. 45, 559-604 (1976)

19. O'NEAL. D. \& K. W. JoY: Glutamine synthetase of Pea leaves. Plant Physiol. 54. 773-779 (1974)

20. Weinstein, J. D. \& P. A. Castelaranco: MgProtoporphyrin IX and $\delta$-aminolevulinic acid synthesis from glutamate in isolated greening chloroplasts. Arch. Biochem. Biophys. 186. 376-382 (1978) 